\title{
A despatch from the future
}

\author{
Matthew Gandy
}

Writing in the spring of 2062 the turmoil of the 2040s should have come as no surprise. The death of King William V in a skiing accident (only one resort remained in Europe because of climate change) led to the accession in 2037 of the now heavily bloated 'playboy prince' Harry to the UK throne (consisting of England and Wales after Scottish independence in 2024 and Irish re-unification in 2030). The steady stream of revelations, including extensive tax avoidance and money laundering, led to public demands for a referendum on the future of the monarchy which was narrowly passed in 2040 but then overruled by a obscure legal move instigated by the 'Bullingdon' faction of the re-elected New Conservatives. Tensions were already running high following the mysterious breakdown of the computerized voting system (outsourced to Belize) during the tightly fought general election of 2039. Following a much delayed and rain drenched Robbie Williams comeback concert in Hyde Park in 2041 (now aged 88) a vast crowd had attempted to storm the now permanently cordoned off 'district 3' created from an amalgamation of London's richest boroughs following the local government reorganization of 2028 that also saw the city's metropolitan boundary extended to the M25 orbital (now doubled in width in both directions). The overstretched and underpaid private security firm Peel, in charge of London's policing, had used live rounds on the irate crowd as they began to storm the high-end Hyde Park 2 residential towers. Following the disturbances in west London a series of security zones in other UK cities were also stormed, along with several police stations, now re-named 'security control points', in Leeds, Manchester and the vast 'Medway super city' (an elongated London overspill zone stretching from Gravesend to Whitstable). Particular fury was vented at these 'control points' because they managed the use of facial algorithms and DNA barcoding to restrict access to banks, hospitals, shopping centres and other buildings on a routine basis. The widespread use of 'electronic clamping', to render citizens 'inactive', and thereby excluded from society, had reached levels of 40 per cent by the early 2040s, with widening disparities in income and life expectancy across different parts of the city.

The eventual abandonment of the vast 'Thames Barrier 2' project in 2025, after the UK's third debt default, led to the eventual creation of a 'flood park' in 2035 stretching from the now derelict former Olympics site at Stratford to Rainham beyond the city's former metropolitan boundary.

How to cite this book chapter:

Gandy, M. 2013. A despatch from the future. In: Bell, S and Paskins, J. (eds.) Imagining the Future City:

London 2062. Pp. 163-165. London: Ubiquity Press. DOI: http://dx.doi.org/10.5334/bag.y 
The Thames Gateway development scheme initiated in the 1990s had been eventually dropped because of the withdrawal of insurance cover for new homes, leading to further pressure on the city's housing market, which contributed to the widespread 'shelter riots' of 2021, 2037 and especially 2042. The shortage of land for new housing had also been exacerbated by two further developments: the construction of a new international airport, with four runways, in Leytonstone, which had displaced over 200,000 people; and the growing trend for 'urban villas', constructed in a dizzying array of architectural styles on individual 1 hectare plots, sold principally to overseas buyers at 1 trillion dollars apiece.

The aerial view of London in 2062 is dominated by the green wedge-shaped expanse of its controlled flood zone beyond which we can observe a patchwork of giant fields in which all food production is managed by the food-healthcare conglomerate BupaFood Incorporated (the term 'food' itself had eventually been trademarked in 2031 following unexplained interruptions to the supply of basic commodities such as wheat, milk and soya). The now permanent presence of vast stretches of standing water in east London, following the disastrous flood of 2033, has had some unexpected consequences for the city's twelve million inhabitants: new strains of encephalitis, malaria and even dengue fever have become an everyday hazard for low-income populations, now almost exclusively concentrated in the heavily overcrowded and dilapidated 'non investment' zones. Although the word 'slum' is forbidden in all mass media outlets, now controlled by just one magnate, tattered copies of books by Mike Davis, David Harvey and other writers still circulate on the black market, in contravention of the 'digitization' edict of 2040, which sought to bring all forms of text-based communication under central control by Amazon IKL (Information, Knowledge and Leisure) based in New York and Shanghai.

London's manager, the term 'mayor' was dropped because of its democratic connotations, has been appointed on a quinquennial basis by the now enlarged Corporation of London since 2028, when they assumed full control of the metropolitan region for planning, security and 'policy delivery' (all services are now outsourced and the term 'public' is seen as highly anachronistic). Given the size and complexity of London the attempt by the Corporation and its sponsors to control all aspects of everyday life has its limits: a glance from the thickened glass windows of bullet trains, on the eventually completed Crossrail project, reveals the tell-tale signs of local food production and clandestine allotments nestling between abandoned buildings in the city's flood zone. Only the other day a neighbour gave me some ripe mangoes that had been secretly cultivated in our street. 


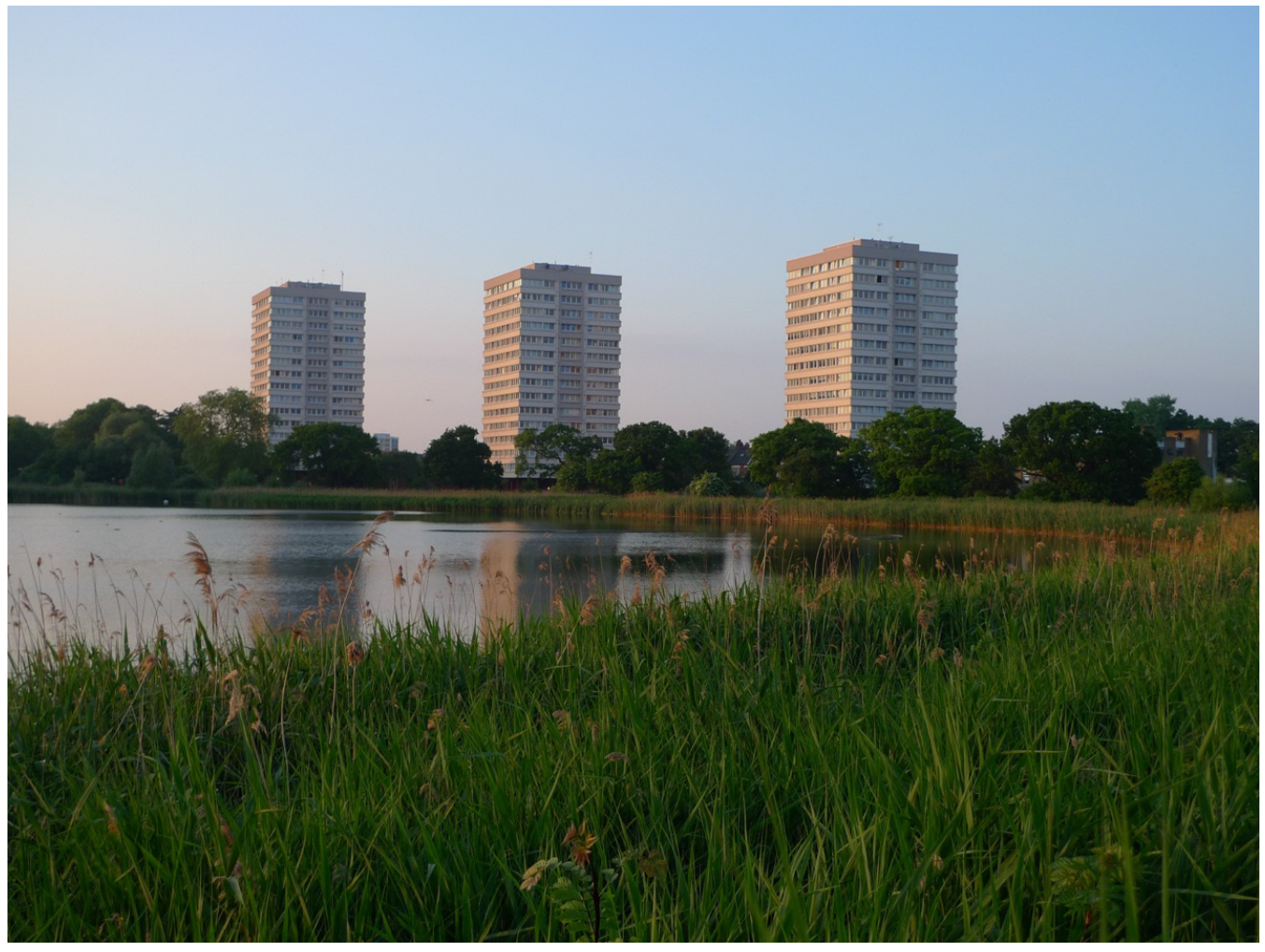

